\title{
ANALISIS AKSES DAN PENGGUNAAN MEDIA SOSIAL OLEH RUMAH TANGGA DAN INDIVIDU DI KOTA BATU JAWA TIMUR
}

\section{ANALYSIS OF ACCESS AND THE USE OF SOCIAL MEDIA BY HOUSEHOLD AND INDIVIDUAL IN BATU CITY, EAST JAVA}

\author{
Trisnani \\ Peneliti Madya Balai Pengembangan SDM dan Penelitian (BPSDMP) Kominfo Surabaya \\ Jl. Raya Ketajen No. 36, Gedangan, Sidoarjo \\ Email : tris010@kominfo.go.id \\ Diterima : 9 Juni 2018| Direvisi : 27 Juni 2018| Disetujui : 9 Agustus 2018
}

\begin{abstract}
Analysis of Access And The Use of Social Media By Household And Individual In Batu City, East Java has been done in June 2017. Using survey method with quantitative descriptive approach, the problem is how much social media use by users? The result is most social media accounts that are frequently accessed, Facebook,. Instagram, google +, linkedin, Twitter, path, WhatsApp, BBM, Youtube. Average duration in accessing social media is 1-3 hours/day. Topics that are often noticed in social media is entertainment. In instant messaging group; job topics becomes crowded/viral discussed, because coincide with registration of Candidates Civil Servants (CPNS). Instant account messaging is frequently used is WhatsApp, The average length of communicate, at most 1-3 hours/day. Evidently, men more often use WhatsApp than women. More men follows instant messaging group than women. Based on education, mobile phone ( $2 G)$ more often used by junior high school student to communicate.
\end{abstract}

Keywords : access, use, social media, household, individual

\begin{abstract}
Abstrak
Analisis Akses dan Penggunaan Media Sosial oleh Rumah Tangga Dan Individu di Kota Batu Jawa Timur, survei ini telah dilakukan pada bulan Juni 2017. Menggunakan metode survei dengan pendekatan deskriptif kuantitatif, permasalahnya seberapa besar pemanfaatan media sosial oleh penggunanya? Hasilnya sebagian besar akun media sosial yang sering di akses adalah Facebook,Instagram, Google+, Linkedin, Twitter, Path, WhatsApp, BBM, Youtube. Rata-rata lama responden mengakses media sosial dalam satu hari 1-3 jam/hari. Topik yang sering menjadi perhatian di media sosial adalah hiburan. Sedangkan di grup instant messaging adalah topik pekerjaan yang menjadi viral, karena bertepatan dengan pendaftaran Calon Pegawai Negeri Sipil (CPNS). Akun instant messaging yang sering digunakan adalah WhatsApp. Rata-rata lama berkomunikasi melalui instant massaging dalam satu hari adalah 1-3 jam. Ternyata jenis kelamin laki-laki lebih sering menggunakan WhatsApp daripada perempuan. Laki-laki lebih banyak mengikuti grup instant messaging dari pada perempuan. Berdasarkan pendidikan handphone (2G) lebih sering digunakan oleh SMP untuk berkomunikasi.
\end{abstract}

Kata Kunci: akses ,penggunaan, media sosial, rumah tangga, individu

\section{PENDAHULUAN}

Saat ini Teknologi Informasi dan Komunikasi (TIK) merevolusi cara hidup manusia mulai dari cara berkomunikasi, cara belajar, cara bekerja, cara berbisnis dan lain-lain. TIK mengubah proses kerja dari analog menjadi digital, mobile dan virtual. Hal tersebut menyebabkan proses kerja meningkat tajam di berbagai aktivitas modern masyarakat termasuk di rumah tangga. Oleh karena itu, TIK dapat meningkatkan kualitas hidup masyarakat dan secara tidak langsung mengharuskan masyarakat untuk menggunakannya dalam segala aktivitas.

Teknologi Informasi dan Komunikasi (TIK) setiap saat setiap waktu bersamaan dengan ilmu pengetahuan selalu ada perkembangan yang baru tidak pernah tahu bahwa saat ini, kita telah memasuki era dimana informasi dan komunikasi telah banyak merubah perilaku di masyarakat tidak hanya di level individu, komunitas, kelompok maupun organisasi. Tetapi sudah menjadi media 
komunikasi untuk penyampaian kesepakatan bersama dalam memecahkan permasalahan

Teknologi informasi dan Komunikasi (TIK) berkembang seiring dengan tingkat kebutuhan manusia, semakin modern kehidupan manusia, maka semakin modern pula teknologi. Setiap teknologi mempunyai pengaruh baik positif maupun negatif, Berdampak positif karena dapat mendorong lahirnya berbagai inovasi baru yang mempermudah hidup manusia. Berdampak negatif karena TIK memberikan dampak pada kehidupan sosial budaya salah satunya dimana norma-norma yang berlaku dimasyarakat seringkali diabaikan. Dampak negatif yang lebih jauh dapat mendorong terjadinya kerusakan moral. TIK juga menjadikan masyarakat menjadi kurang peka terhadap kehidupan sosial seperti mengurangi intensitas tatap muka yang terjadi dalam organisasi ataupun sosial masyarakat. Kini manusia seakan tak lepas dari peran teknologi komunikasi (Proposal Indikator TIK Kominfo, 2017 ).

Penggunaan teknologi informasi penggunaan internet yang sudah memiliki berbagai aplikasi seperti media sosial, merupakan salah satu media dimana para penggunanya dapat mencari informasi, saling berkomunikasi dan menjalin pertemanan secara online. Ragam media sosial adalah facebook, twitter, line, bbm, WhatsApp, instagram, path, ask.fm, linkedin, snapchat dan beberapa media sosial yang lain.

Keberadaan media sosial pada saat ini sangatlah memberikan pengaruh yang kuat terhadap perubahan di dalam masyarakat dan sosial. Pada saat ini media sosial telah membuat ide tentang sebuah 'global village' yang diungkapkan Mc Luhan tahun 1960-an menjadi lebih nyata. Dimana dalam era ini manusia telah saling terhubung melalui teknologi komunikasi internet dengan media sosial yang merupakan bagiannya. Ide dari Mc Luhan tersebut juga senada dengan sebuah istilah yang diungkapkan Friedman yaitu "flat world" (dunia datar) di awal abad 21, dimana orang-orang akan saling terhubung melalui komputer dan semakin cepatnya transfer informasi melalui kabel optik. Hal ini dapat dikatakan sebagai revolusi modern dimana hampir dapat menghilangkan batasan antara waktu dan ruang (Toivo, 2012).

Dalam bukunya Hemawan, 2009 menyatakan bahwa dalam penggunaan media sosial juga dapat dengan mudah menciptakan suatu forum dimana individu satu dengan yang lain dapat saling berkomunikasi dan bertukar pikiran satu sama lain.
Dalam hal ini sangat mudah membuat individu berkomunikasi dan berkomentar tentang berbagai topik maupun kasus yang dibahas oleh individu lain. Individu juga dapat membangun asumsi, emosi dan kepercayaan melalui komentar maupun sudut pandang maupun pemikiran individu lain dalam media sosial, memungkinkan kita dapat secara reaktif berkomentar maupun berkesimpulan.

Media sosial saat ini banyak yang menggunakan untuk kepentingan bersosialisasi maupun sebagai penyampaian pesan baik oleh individu maupun kelompok. Dari latar belakang tersebut diatas dapat diambil permasalahan yaitu seberapa besar penggunaan media sosial sebagai media komunikasi oleh individu dalam rumah tangga? Sedangkan tujuan penelitian ini untuk mendapatkan data dan informasi tentang akses media sosial oleh individu.

Manfaat Penelitian adalah secara teoritis hasil peneitian ini adalah data dan informasi sebagai masukan kementerian komunikasi dan informatika dalam menentukan kebijakan di bidang penggunaan TIK dan komunikasi pelayanan publik. Kedua secara Praktis penelitian ini diharapkan dapat menjadi bahan referensi bagi yang membutuhkan dan dapat menjadi bahan masukan bagi pengguna aplikasi media sosial serta untuk menambah wawasan bagi pengguna aplikasi media sosial.

Teori yang digunakan adalah Uses and Gratification yang menjadi dasar utama adalah pendekatan penggunaan media, berfokus pada konsumen media daripada pesan media sebagai titik awalnya, menelusuri perilaku komunikasi artinya pengalaman langsungnya dengan media. Pendekatan ini memandang audiens sebagai pengguna yang aktif, sedangkan media menggunakan secara pasif. Jadi pendekatan ini tidak mengharapkan adanya hubungan langsung antara pesan dan pengaruh, tetapi sebaliknya merumuskan pesan- pesan yang akan digunakan oleh audiens, bahwa penggunanya tersebut bertindak sebagai variabel penghalang dari proses pengaruh. Disini audiens aktif dan diarahkan oleh tujuan. Audiens sangat bertanggung jawab dalam memilih media untuk memenuhi kebutuhan mereka sendiri. Dalam pandangan ini, media dianggap sebagai perantara yang besar, mereka tahu kebutuhan mereka dan bagaimana memenuhi kebutuhan tersebut (Little John, 2009).

Teori Uses and Gratification berasumsi bukan media mengubah sikap dan perilaku audiens, tetapi audiens yang aktif dan selektif dalam menentukan sikap dan perilakunya. Jadi penelitian ini audiens 
bisa memilih dan menggunakan media dengan caranya sendiri dan bagaimana seseorang menggunakan media sangat dipengaruhi oleh kerangka pemikiran serta lingkungan sosial dimana mereka bertempat tinggal. Pemikiran seseorang sangat dipengaruhi oleh latar belakang pengalaman, pendidikan, baik pendidikan secara langsung maupun proses pembelajaran dari orang lain.

Penelitian ini dirancang untuk merepresentasikan dan menyediakan informasi kuantitatif tentang dua hal penting yaitu tentang penggunaan TIK meliputi tingkat literasi (penggunaan) TIK (device-komputer, laptop, hpdan internet) yang terdiri dari frekuensi dan durasi, tujuan, aktivitas serta tempat penggunaan. Dan yang kedua tentang akses dan penggunaan media sosial oleh rumah tangga dan individu. Aspek yang diteliti ini diperoleh dari data primer dan sekunder.

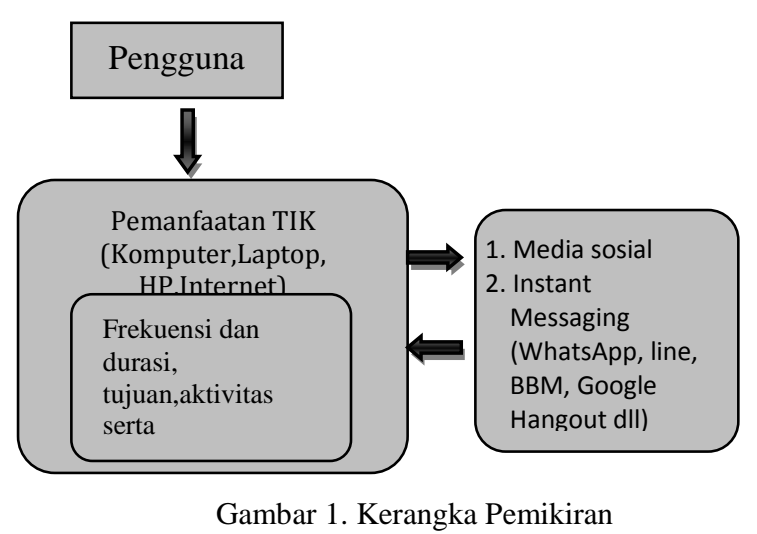

\section{METODE}

Penelitian ini menggunakan metode survei, informasi dikumpulkan dari responden dengan menggunakan kuesioner. Penelitian dibatasi pada penelitian yang datanya dari sampel atas populasi untuk mewakili seluruh populasi Singarimbun dalam (Trisnani, 2015)

Dengan demikian penelitian adalah penelitian yang mengambil dari satu populasi dan menggunakan kuesioner. Sebagai alat pengumpulan data yang pokok, untuk unit analisis dalam penelitian ini adalah individu, satu ditujukan kepada satu orang pengguna sebagai responden. Sedangkan karakteristik responden adalah usia 9 64 tahun.
Tabel 1.

Lokasi penelitian di kota Batu Jawa Timur

\begin{tabular}{lllll}
\hline Kota Batu & Urban & Batu & Sidomulyo & 24 \\
\cline { 2 - 5 } Jawa & Urban & Junrejo & Beji & 24 \\
\cline { 2 - 5 } Timur & Urban & Bumiaji & Pandanrejo & 24 \\
\cline { 2 - 5 } & Urban & Bumiaji & Bumiajibulukerto & 24 \\
\cline { 2 - 5 } & Urban & Bumiaji & Punten & 24 \\
\hline
\end{tabular}

Pada setiap desa dipilih secara acak 2 Rukun Tetangga (RT). Kedua rukun tetangga tersebut dipilih berdasarkan status ekonomi dominan. RT pertama dipilih yang mewakili RT menengah ke atas, sedangkan RT kedua dipilih yang mewakili RT menengah ke bawah.Untuk desa di pedesaan, RT pertama dekat dengan pusat desa dan RT kedua yang agak jauh dari pusat desa. Informasi ini dapat diperoleh di kantor desa/kelurahan. Pada setiap RT dipilih secara acak 12 rumah tangga, menggunakan daftar rumah tangga yang ada pada RT tersebut atau listing di tempat. Selanjutnya pada setiap rumah tangga dipilih 1 orang atau individu yang memenuhi syarat sebagai responden

Individu merupakan unit terkecil pembentuk masyarakat. Dalam ilmu sosial individu berarti bagian terkecil dari kelompok masyarakat yang tidak dapat dipilah lagi menjadi bagian yang lebih kecil. Individu berasal dari kata yunani yaitu "individium" artinya "tidak terbagi". Dalam ilmu sosial paham individu, Individu merupakan yang terbatas yaitu sebagai manusia perseorangan bukan sebagai manusia keseluruhan. Contoh, suatu keluarga atau rumah tangga terdiri dari ayah, ibu, dan anak. Ayah sebagai individu dalam kelompok sosial itu, yang sudah tidak dapat dibagi lagi ke dalam satuan yang lebih kecil. Jadi individu adalah bagian anggota keluarga yang menjadi responden, bisa anak, ibu dan bapak, yang memenuhi syarat sebagai responden.

Tabel 2.

Contoh Tabel Acak "Kish Grid"

\begin{tabular}{|c|c|c|c|c|c|c|c|c|c|c|}
\hline \multirow[t]{2}{*}{ No } & \multicolumn{2}{|c|}{$\begin{array}{l}\text { Anggota Rumah } \\
\text { Tangga yang } \\
\text { tinggal di rumah } \\
\text { ini } \\
\end{array}$} & & \multicolumn{7}{|c|}{ Rumah ke } \\
\hline & $\begin{array}{l}\text { Gender } \\
\text { /Jenis } \\
\text { kelamin }\end{array}$ & $\begin{array}{c}\text { Age / } \\
\text { Umur } \\
\text { (tahun) }\end{array}$ & 1 & 2 & 3 & 4 & 5 & 6 & 7 & 8 \\
\hline 1 & $\mathrm{P}$ & & 1 & 1 & 1 & 1 & 1 & 1 & 1 & 1 \\
\hline 2 & $\mathrm{~L}$ & & 1 & 2 & 1 & 2 & 1 & 2 & 1 & 2 \\
\hline 3 & $\mathrm{~L}$ & & 1 & 2 & 3 & 1 & 2 & 3 & 1 & 2 \\
\hline 4 & $\mathrm{P}$ & & 1 & 2 & 3 & 4 & 1 & 2 & 3 & 4 \\
\hline
\end{tabular}




\begin{tabular}{ccccccccccc}
\hline 5 & $\mathrm{~L}$ & $\mathrm{P}$ & 1 & 2 & 3 & 4 & 5 & 3 & 4 & 5 \\
\hline 6 & $\mathrm{~L}$ & $\mathrm{P}$ & 1 & 2 & 3 & 4 & 5 & 6 & 3 & 6 \\
\hline 7 & $\mathrm{~L}$ & $\mathrm{P}$ & 1 & 2 & 3 & 4 & 5 & 6 & 7 & 4 \\
\hline 8 & $\mathrm{~L}$ & $\mathrm{P}$ & 1 & 2 & 3 & 4 & 5 & 6 & 7 & 8 \\
\hline 9 & $\mathrm{~L}$ & $\mathrm{P}$ & 1 & 2 & 3 & 4 & 5 & 6 & 7 & 8 \\
\hline 10 & $\mathrm{~L}$ & $\mathrm{P}$ & 1 & 2 & 3 & 4 & 5 & 6 & 7 & 8 \\
\hline
\end{tabular}

\section{Teknik Pengumpulan Data}

a. Data Primer diperoleh melalui daftar kuisioner berstruktur yang diberikan kepada responden dan dilakukan wawancara untuk memperoleh data dan informasi. Sedangkan data sekunder, yaitu mempelajari berbagai jenis dokumen yang relevan dengan penelitian.

b. Populasi diambil sesuai dengan data kepadatan penduduk desa nelayan masing-masing desa di ambil 24 responden sebagai sampel penelitian jadi dari lima desa semua berjumlah 120 responden. Jumlah tersebut dikategorikan sudah mewakili populasi.

c. Analisis adalah diskriptif kuantitatif, untuk memberikan gambaran atas jawaban dari hasil penelitian. Data diolah dengan program SPSS. Setelah diolah, dikategorikan di analisis kemudian disimpulkan.

\section{HASIL DAN PEMBAHASAN}

Berikut adalah hasil analisa data

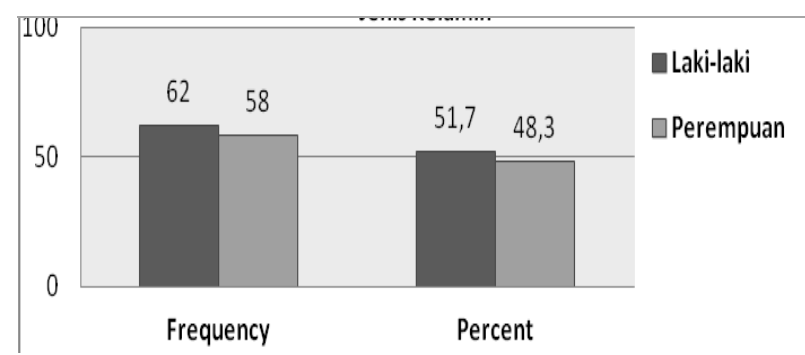

Grafik 1. Profil Pengguna TIK Secara Individu (survei TIK BPSDMP Kominfo Surabaya 2017)

Melihat grafik 1. diatas maka jenis kelamin responden laki-laki lebih dominan dibandingkan jenis kelamin perempuan. Laki-laki sebesar 51,7 \% sedangkan perempuan sebesar 48, $3 \%$ Total sebesar 100,0 \%. Ini berarti sebaran kuesioner terhadap seratus duapuluh responden hasilnya menunjukkan laki-laki lebih dominan.

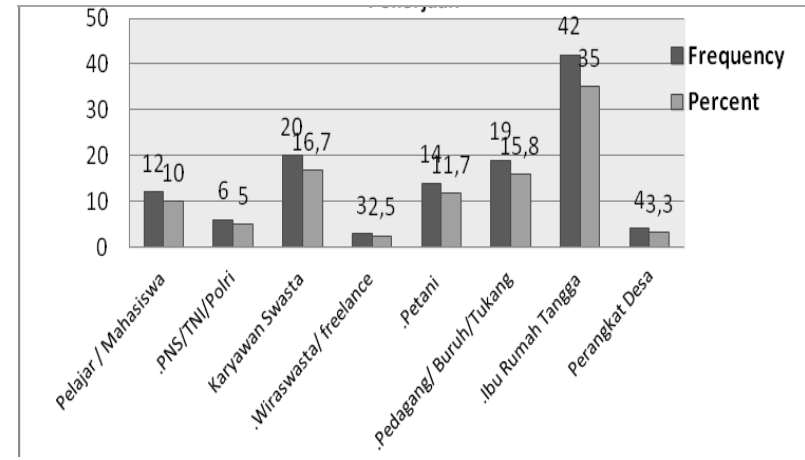

Grafik 2. Pekerjaan Pengguna TIK Secara Individu (survei TIK BPSDMP Kominfo Surabaya 2017)

Melihat grafik 2 pekerjaan responden yang paling banyak menduduki urutan pertama adalah Ibu Rumah Tangga sebanyak 42 responden atau $35,0 \%$. Urutan yang kedua karyawan swasta, sebanyak 20 responden atau $16,7 \%$. Urutan ke tiga Pedagang/Buruh Tukang sebanyak 19 responden atau $15,8 \%$. Urutan ke empat petani sebanyak 14 responden atau $11,7 \%$. Urutan ke lima pelajar/mahasiswa sebanyak 12 responden atau $10,0 \%$. yang lain bisa melihat dalam grafik diatas.

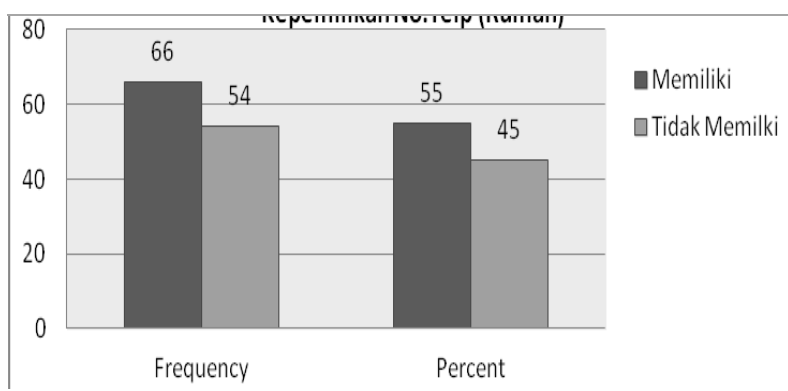

Grafik 3. Kepemilikkan Telephone Rumah Pengguna TIK secara Individu (survei TIK BPSDMP Kominfo Surabaya 2017)

Melihat grafik 3. Kepemilikan Nomor Telpon rumah, yang menyatakan memiliki sebanyak 66 responden atau sebesar 55,0\%. Yang tidak memiliki sebanyak 54 responden atau sebesar $45,0 \%$. Total sebesar $100,0 \%$. Sebetulnya melihat grafik tersebut antara kepemilikan dan yang tidak memiliki hampir sama, karena saat ini sudah era teknologi informasi bersamaan dengan perkembangan hal tersebut banyak/model alat komunikasi sudah banyak variasinya dan makin praktis seperti telepon seluler sudah semakin murah sudah terjangkau harganya oleh masyarakat sehingga masyarakat sudah banyak yang beralih ke alat komunikasi yang lebih praktis. 


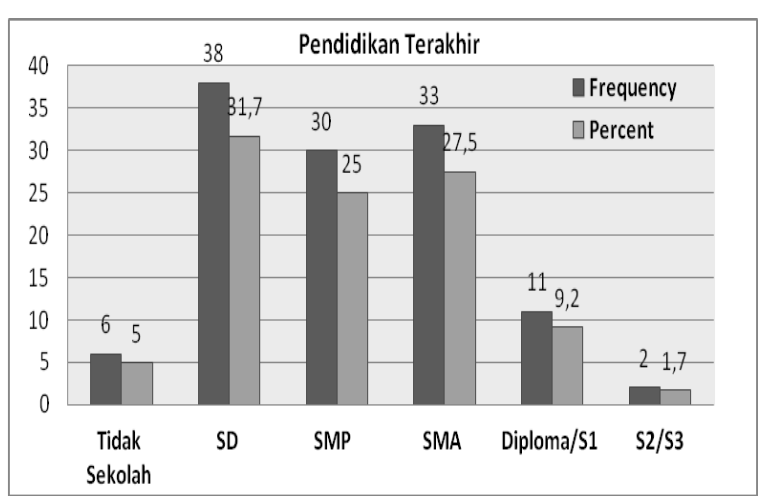

Grafik 4. Pendidikkan Terakhir (survei TIK BPSDMP Kominfo Surabaya 2017)

Melihat pada grafik 4. Tingkat pendidikan terakhir, yang dominan adalah SD mencapai sebanyak 38 responden atau sebesar 31,7 \%. Menduduki urutan ke dua pendidikan SMA mencapai sebesar 33 responden atau sebesar 27,5 $\%$. Menduduki urutan ke tiga pendidikan SMP mencapai sebanyak 30 responden atau sebesar 25,0 $\%$. Menduduki urutan ke empat Diploma/S1 sebanyak 11 responden atau sebesar 9,2\%. Sedangkan tidak sekolah mencapai sebanyak 6 responden atau 5,0 \%. Urutan yang terakhir pendidikan S2/S3 hanya mencapai sebanyak 2 responden atau $1,7 \%$. Total sebesar $100,0 \%$.

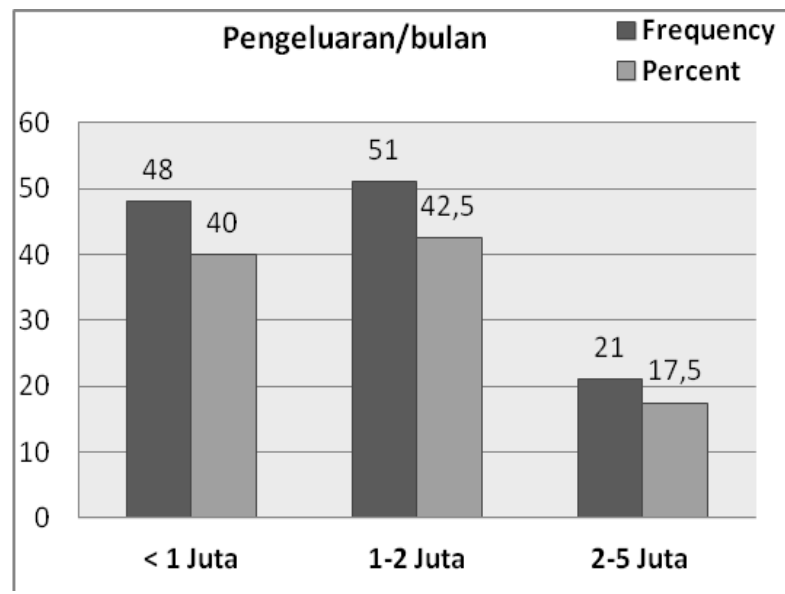

Grafik 5. Pengeluaran per Bulan (survei TIK BPSDMP Kominfo Surabaya 2017)

Melihat grafik 5 terkait pengeluaran perbulan, yang menyatakan kurang dari 1 juta sebanyak 48 responden atau 40,0 \%. Urutan ke dua yang menyatakan 1-2 Juta sebanyak 51 responden atau sebesar 42,5 \%. 2-5 juta sebanyak 21 responden atau sebesar $17,5 \%$. Total sebesar 100,0 \%. Jadi pengeluaran/bulan yang dominan adalah satu juta hingga dua juta per bulan.

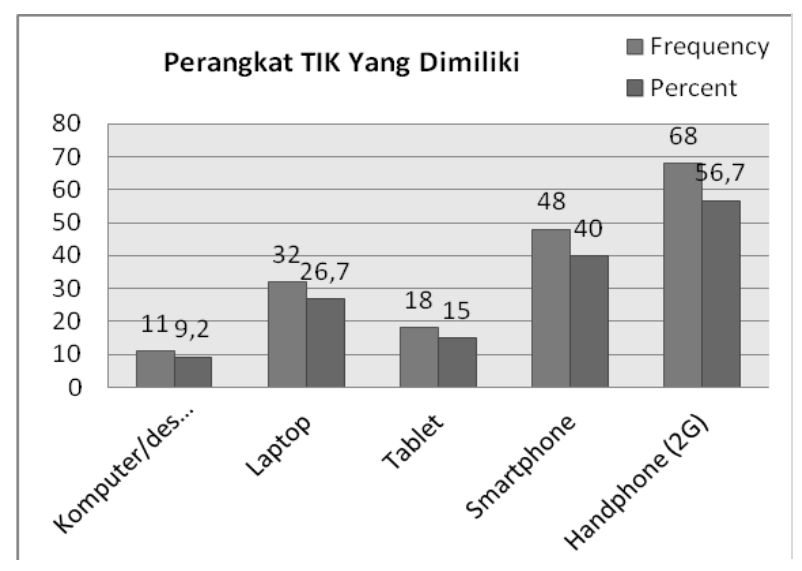

Grafik 6. Perangkat TIK yang dimiliki (survei TIK BPSDMP Kominfo Surabaya 2017)

Melihat grafik 6. Macam-macam perangkat yang dimiliki individu, yang menyatakan memiliki Komputer/desktop sebanyak 11 responden atau sebesar 9,2 \%. Memiliki laptop sebanyak 32 responden atau sebesar 26,7\%. Memiliki smartphone sebanyak 48 responden atau sebesar 40,0\%. Memiliki tablet sebanyak 18 responden atau sebesar $15,0 \%$. Memiliki Handphone (2G) sebanyak 68 responden atau sebesar 56, $7 \%$. Total sebesar 100,0 \%.

Dari kepemilikan perangkat TIK maka handphone (2G) menduduki peringkat pertama hingga mencapai sebesar 56,7 \%. Smartphone menduduki peringkat ke 2, mencapai sebesar 40,0 $\%$. Peringkat ke tiga laptop hingga mencapai sebesar 26,7 \%. Sedangkan yang lainnya bisa melihat pada grafik 6. Tersebut diatas. Antara peringkat satu hingga ke tiga lagi dibutuhkan masyarakat. Handphone (2G) masih dimiliki di masyarakat desa, Smartphone saatnya lagi ngetren di masyarakat. Sedangkan Laptop memang dibutuhkan bagi pelajar/mahasiswa dan pekerja.

Penggunaan perangkat TIK oleh individu dalam 3 bulan terakhir

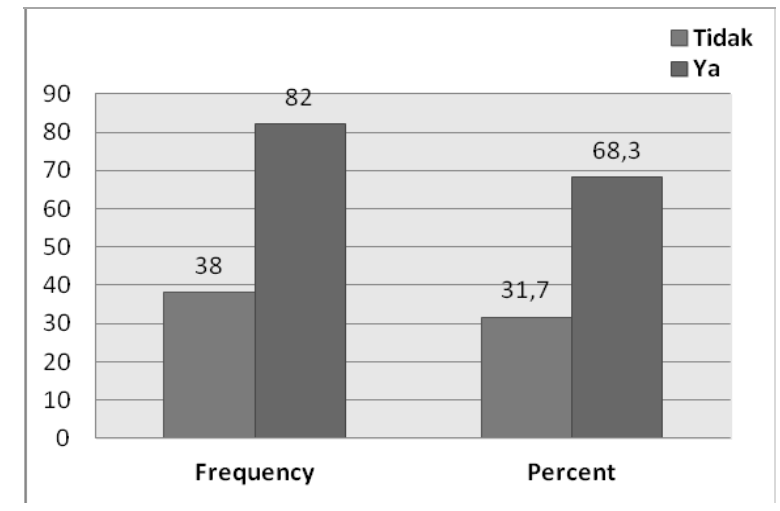

Grafik 7. Penggunaan perangkat TIK dalam 3 bulan terakhir (survei TIK BPSDMP Kominfo Surabaya 2017) 
Melihat grafik 7 terkait penggunaan perangkat TIK dalam 3 bulan terakhir, yang menyatakan menggunakan sebanyak 82 responden atau $68.3 \%$. Tidak menggunakan sebanyak 38 responden atau $31,7 \%$. Total sebesar $100 \%$.

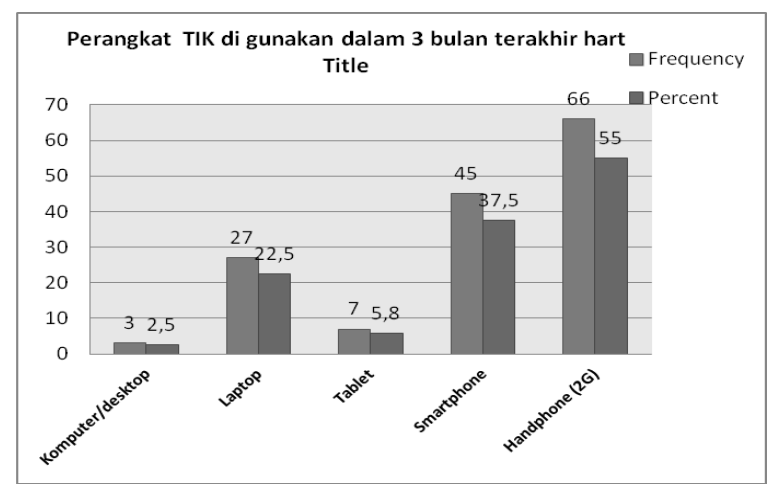

Grafik 8. Perangkat TIK digunakan dalam 3 bulan terakhir (survei TIK BPSDMP Kominfo Surabaya 2017)

Melihat grafik 8 . Terkait penggunaan perangkat yang digunakan dalam 3 bulan terakhir. Handphone (2G) menduduki teratas mencapai sebanyak 66 responden atau sebesar 55, $0 \%$. Smartphone menduduki urutan ke dua mencapai sebanyak 45 responden atau sebesar 37,5\%. Laptop menduduki urutan ke tiga mencapai sebanyak 27 responden atau sebesar $22,5 \%$. Tablet menduduki urutan ke empat mencapai sebanyak 7 responden atau sebesar $5,8 \%$. Komputer/desktop menduduki urutan terakhir mencapai sebanyak 3 responden atau sebesar 2,5 \%. Pada grafik 8 ini apabila dibandingkan dengan kepemilikan perangkat pada grafik 6. perangkat TIK antara urutan ke satu sampai terakhir hampir sama dengan macam perangkat yang dimiliki.

Tujuan Penggunaan Perangkat TIK Ketika Tidak Terhubung Internet (selama 3 bulan terakhir)

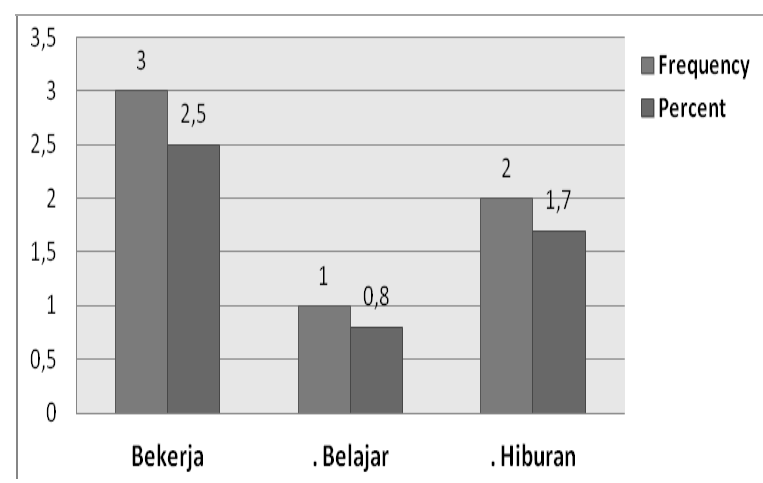

Grafik 9. Tujuan Penggunaan Komputer ketika tidak terhubung internet (survei TIK BPSDMP Kominfo Surabaya 2017)
Melihat grafik 9. Terkait dengan penggunaan komputer. Yang menyatakan komputer untuk bekerja sebanyak 3 responden, atau sebesar 2,5\%. Komputer untuk belajar sebanyak 1 responden atau sebesar 0,8 $\%$. Untuk hiburan sebanyak 2 responden atau $1,7 \%$.

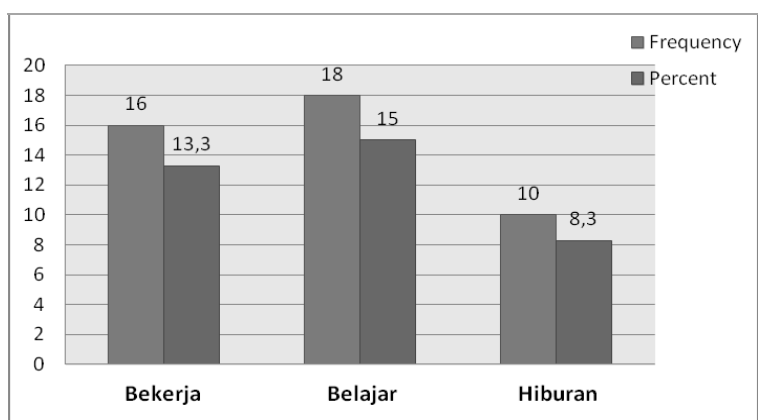

Grafik 10. Tujuan Penggunaan Laptop ketika tidak terhubung internet (survei TIK BPSDMP Kominfo Surabaya 2017)

Melihat grafik 10. Terkait tujuan penggunaan laptop ketika tidak terhubung internet dalam 3 bulan terakhir ini, untuk bekerja sebanyak 16 responden atau sebesar 13,3\%. Untuk belajar sebanyak 18 responden atau sebesar $15 \%$. Untuk hiburan sebanyak 10 responden atau $8,3 \%$.

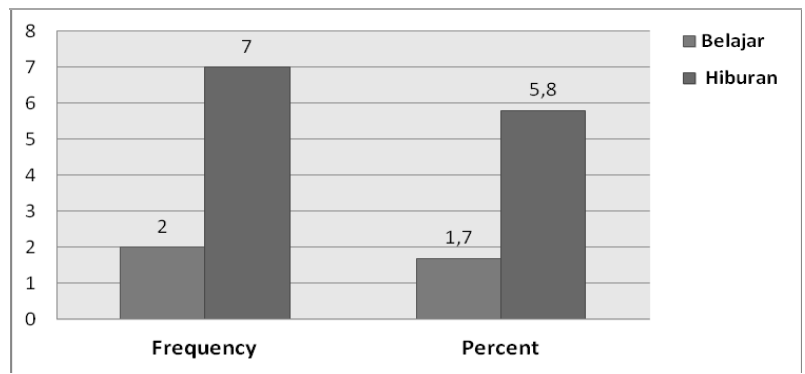

Grafik 11. Tujuan Penggunaan Tablet ketika tidak terhubung internet (survei TIK BPSDMP Kominfo Surabaya 2017)

Melihat grafik 11. Terkait tujuan penggunaan tablet ketika tidak terhubung internet selama 3 bulan terakhir. Untuk belajar sebanyak 2 responden atau sebesar, 1,7 \%. Yang menyatakan untuk hiburan sebanyak 7 responden atau 5,8\%.

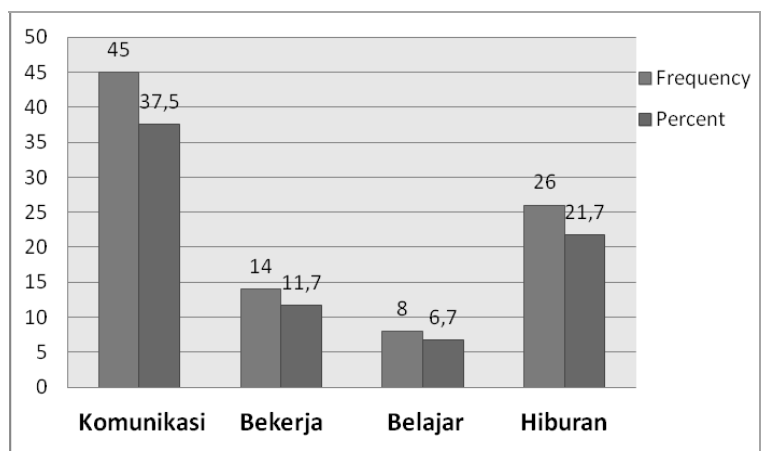

Grafik 12. Tujuan Penggunaan Smartphone ketika tidak terhubung internet (survei TIK BPSDMP Kominfo Surabaya 2017) 
Melihat pada grafik 12 terkait tujuan penggunaan smartphone ketika tidak terhubung internet selama 3 bulan. Yang menyatakan untuk berkomunikasi sebanyak 45 responden atau sebesar $37,5 \%$. Untuk bekerja sebanyak 14 responden atau $11,7 \%$. Untuk belajar sebanyak 8 responden atau sebesar 6,7\%. Untuk hiburan 26 responden atau sebesar $21,7 \%$. Tujuan penggunaan smartphone untuk berkomunikasi menduduki urutan pertama.

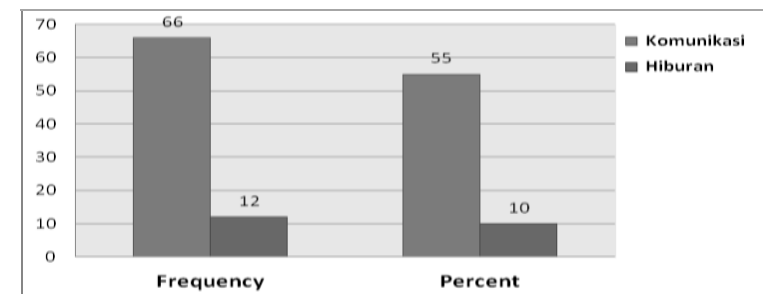

Grafik 13. Tujuan Penggunaan Handphone ketika tidak terhubung internet (survei TIK BPSDMP Kominfo Surabaya 2017)

Melihat grafik 13. terkait penggunaan handphone $(2 \mathrm{G})$ ketika tidak terhubung Internet selama 3 bulan terakhir. Yang menyatakan untuk berkomunikasi sebanyak 66 responden atau sebesar, 55,0 \%. Untuk hiburan 12 responden atau sebesar $10,0 \%$. $9 \%$

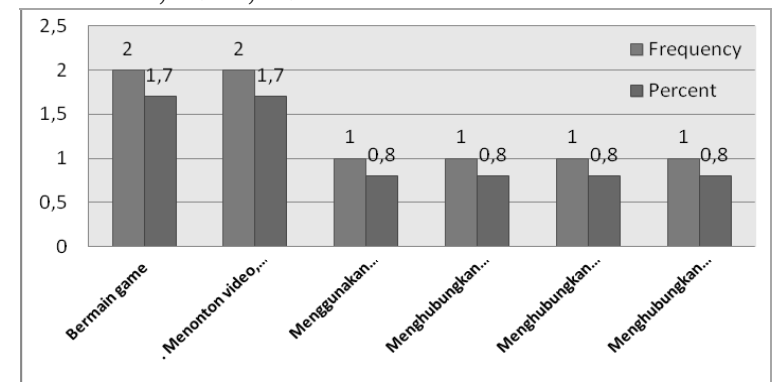

Grafik 14. Aktivitas Penggunaan Komputer ketika tidak terhubung dengan internet (survei TIK BPSDMP Kominfo Surabaya 2017)

Melihat grafik 14. Aktivitas penggunaan komputer ketika tidak terhubung internet yang menyatakan untuk bermain game hanya 2 responden atau $1,7 \%$. Untuk menonton video, mendengarkan musik hanya 2 responden atau 1,7 $\%$. yang lain seperti membaca e-book, menggunakan aplikasi pengolahan dokumen offline: (Ms, Office, Open office, dll, Menghubungkan dan memasang perangkat baru, misal kamera, modem, printer, Menginstall, atau mengkonfigurasi software dan Desain grafis (pengolahan gambar) rata-rata hanya 1 responden saja atau $0,8 \%$.

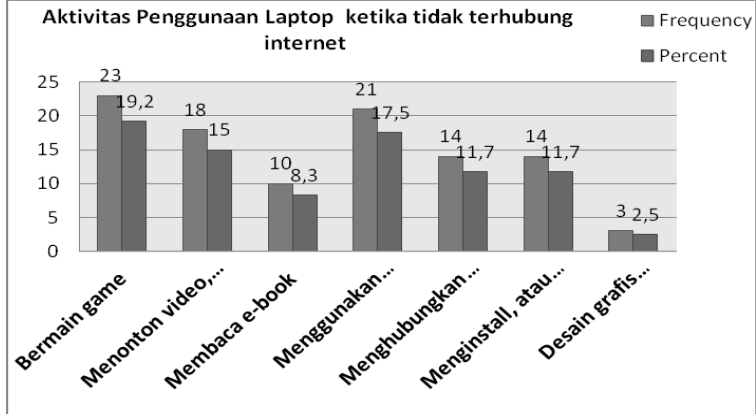

Grafik 15. Aktivitas Penggunaan Laptop ketika tidak terhubung dengan internet (survei TIK BPSDMP Kominfo Surabaya 2017)

Melihat grafik 15. Terkait aktivitas penggunaan laptop ketika tidak terhubung internet. Untuk Menggunakan aplikasi pengolahan dokumen offline: (Ms.Office, Open Office, dll.) sebanyak 21 responden atau $17,5 \%$. Untuk menonton video, mendengarkan musik sebanyak 18 responden atau $15.0 \%$. Untuk bermain game sebanyak 23 responden atau $19,2 \%$.

Untuk menghubungkan dan memasang perangkat baru, misal kamera, modem, printer mencapai sebanyak 14 responden atau $11,7 \%$. Untuk menginstall, atau mengkonfigurasi software mencapai sebesar 14 responden atau $11,, 7 \%$. Untuk membaca e-book sebanyak 10 responden atau 8,3 \%.Untuk desain grafis (pengolahan gambar) msencapai 3 responden atau 2,5\%.

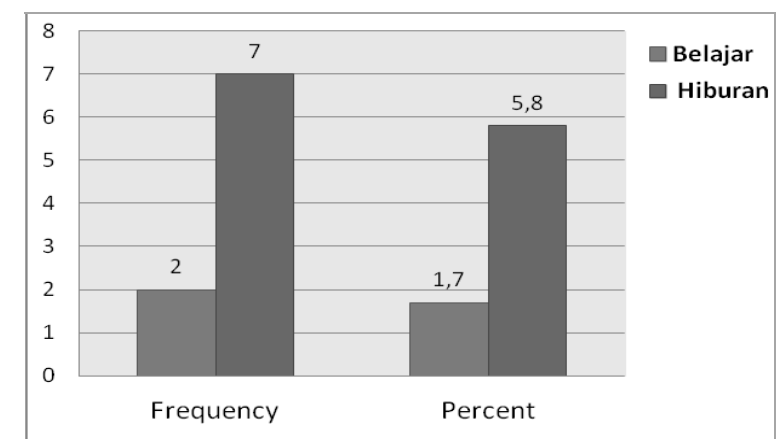

Grafik 16. Pengguna tablet ketika tidak terhubung dengan internet (survei TIK BPSDMP Kominfo Surabaya 2017)

Melihat grafik 16. Terkait aktivitas penggunaan tablet ketika tidak terhubung internet, yang menyatakan untuk belajar sebanyak 2 responden atau $1,7, \%$. Untuk hiburan sebanyak 7 responden atau $5,8 \%$. 


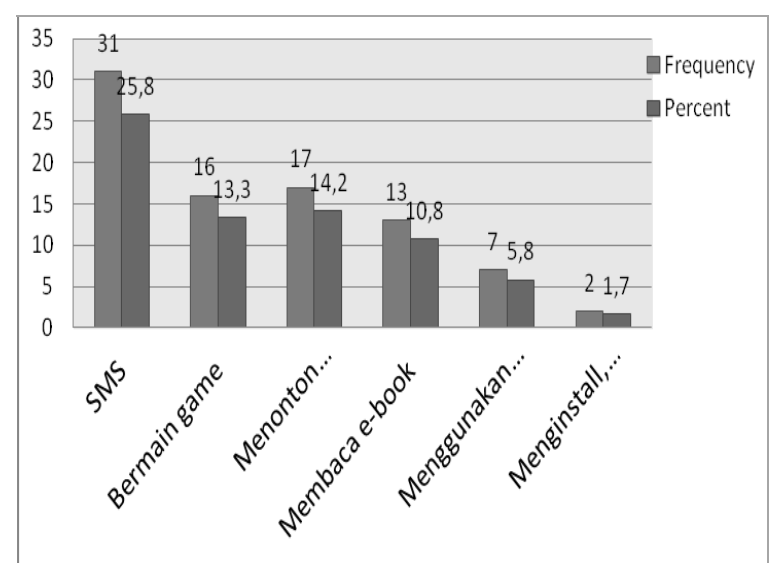

Grafik 17. Pengguna smartphone ketika tidak terhubung dengan internet (survei TIK BPSDMP Kominfo Surabaya 2017)

Melihat grafik 17 terkait aktivitas penggunaan smartphone ketika tidak terhubung internet. tujuannya untuk SMS sebanyak 31 responden atau $25,8 \%$. Untuk menonton video, mendengarkan musik, radio sebanyak 17 responden atau 14,2\%. Untuk bermain game sebanyak 16 responden atau $13,3 \%$. Untuk membaca e-book sebanyak 13 responden atau $10,8 \%$. Untuk menginstall, atau mengkonfigurasi software sebanyak 2 responden atau $1,7 \%$. Untuk menggunakan aplikasi pengolahan dokumen offline: (Ms.Office, Open Office, dll.) sebanyak 7 responden atau 5,8 \%.

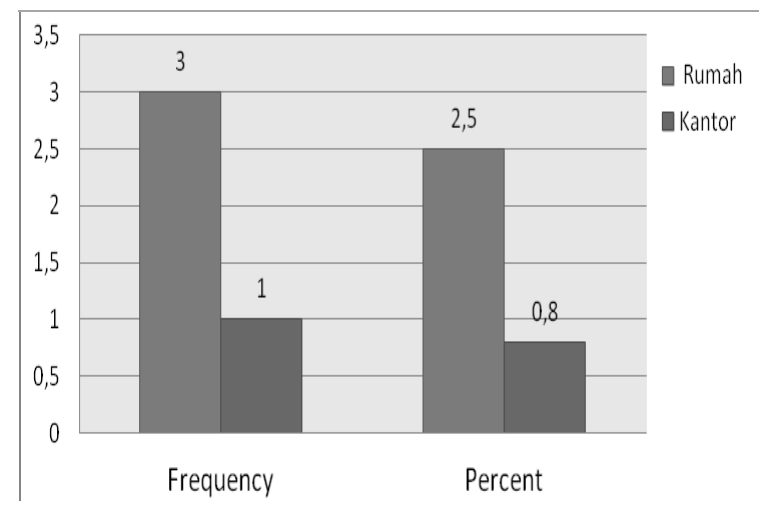

Grafik 18. Tempat Penggunaan Komputer oleh Individu (survei TIK BPSDMP Kominfo Surabaya 2017)

Melihat grafik 18. Tempat Penggunaan komputer oleh individu. Yang menyatakan dirumah sebanyak 3 responden atau 1,0\%. Yang menyatakan tempat menggunakan di kantor hanya 1 responden atau hanya $0,8 \%$. Komputer yang tidak digunakan apabila disandingkan dengan kepemilikan komputer Grafik 6, yang tidak menggunakan di rumah dan di kantor sebanyak 7 responden.

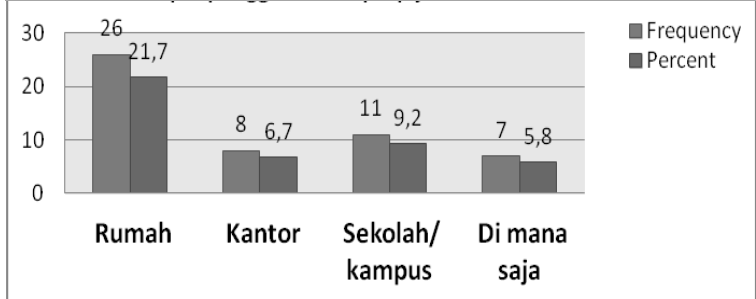

Grafik 19. Tempat Penggunaan Laptop (survei TIK BPSDMP Kominfo Surabaya 2017)

Melihat grafik 19. Tempat penggunaan laptop sebagai berikut yang menyatakan untuk digunakan di rumah sebanyak sebanyak 26 responden atau $21,7 \%$. Untuk digunakan di kantor 8 reponden. Untuk digunakan di sekolah/kampus sebanyak 11 responden atau 9,2\%. Untuk digunakan dimana saja 7 responden atau $5,8 \%$.

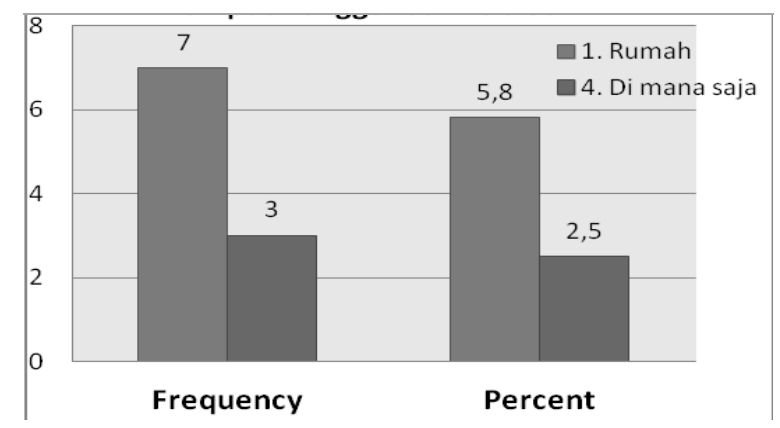

Grafik 20. Tempat Penggunaan Tablet (survei TIK BPSDMP Kominfo Surabaya 2017)

Melihat grafik 20. Tempat penggunaan Tablet. yang menyatakan menggunakan dirumah sebanyak 7 responden atau 5,8 \% yang menyatakan menggunakan di mana saja sebanyak 3 responden atau $2,5 \%$.

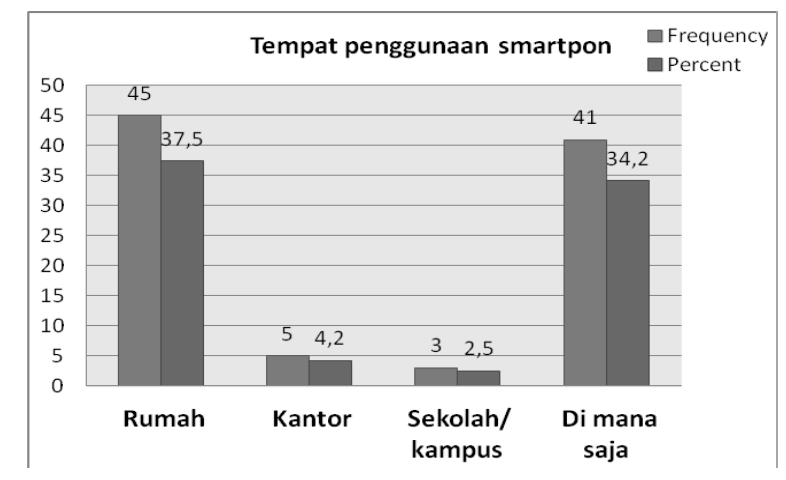

Grafik 21. Tempat Penggunaan Smartphone (survei TIK BPSDMP Kominfo Surabaya 2017)

Melihat grafik 21. tempat penggunaan smartphone, yang menyatakan dirumah sebanyak 45 responden atau 37,5\%. Digunakan di kantor sebanyak 5 responden atau 4,2\%. Digunakan di sekolah/kampus 3 responden atau 2,5\%. 
Digunakan di mana saja sebanyak 41 responden atau $34,2 \%$.

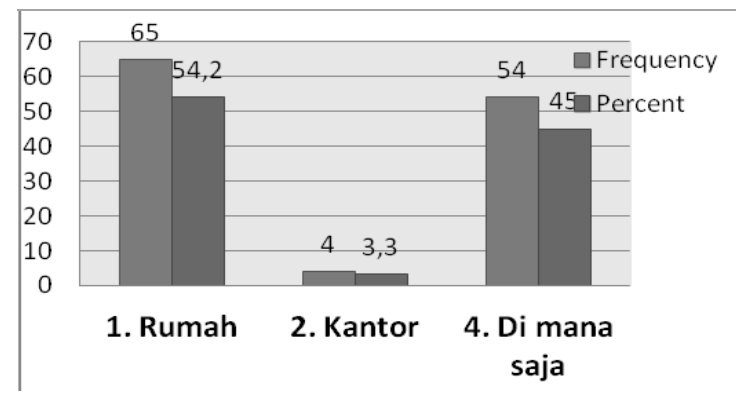

Grafik 22. Tempat Penggunaan Handphone (survei TIK BPSDMP Kominfo Surabaya 2017)

Melihat grafik 22. terkait tempat penggunaan handphone $(2 \mathrm{G})$. Yang menyatakan digunakan di rumah sebanyak 65 responden atau $54,2 \%$. Yang menyatakan penggunaan di kantor sebanyak 4 responden atau 3,3\%. Digunakan di mana saja sebanyak 54 responden atau 45 , )\%.

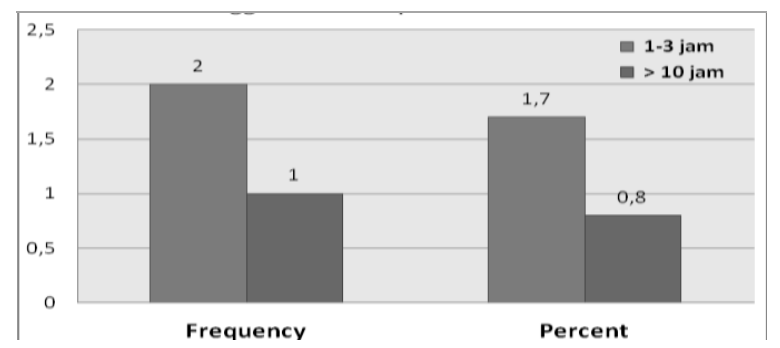

Grafik 23. Lama Menggunakan Komputer oleh Individu (survei TIK BPSDMP Kominfo Surabaya 2017)

Melihat grafik 23. Lama penggunaan computer yang menyatakan paling lama 1-3 jam hanya 2 responden atau 1,7\%. Yang menyatakan lebih besar sepuluh jam hanya 1 responden.

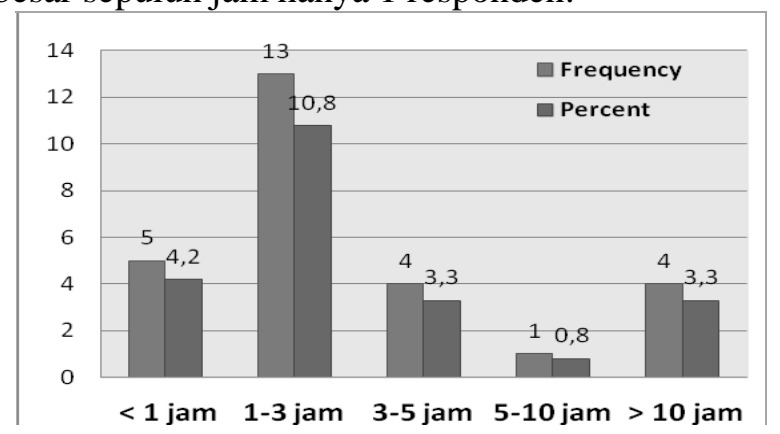

Grafik 24. Lama Penggunaan Laptop oleh Individu (survei TIK BPSDMP Kominfo Surabaya 2017)

Melihat grafik 24. lama penggunaan komputer. kurang dari satu jam sebanyak 5 responden atau 4,2 $\%$, lama 1-3 jam sebesar 13 responden atau 10,8 $\%$. 3-5 jam sebanyak 4 responden atau 3,3\%. lama 5-10 sebanyak 1 responden atau 0,8\%. Lama lebih besar dari sepuluh sebanyak 4 responden atau 3,3 $\%$.

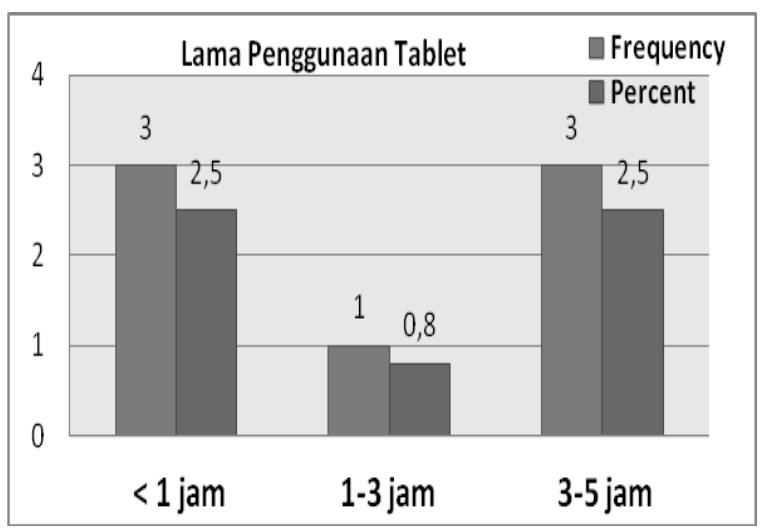

Grafik 25. Lama Penggunaan Tablet oleh Individu (survei TIK BPSDMP Kominfo Surabaya 2017)

Melihat grafik 25. terkait lama penggunaan tablet yang menyatakan kurang dari satu jam sebanyak 3 responden. 1-3 jam hanya 1 responden atau 0,8\%. 3-5 jam sebanyak 3 responden atau 2,5 $\%$.

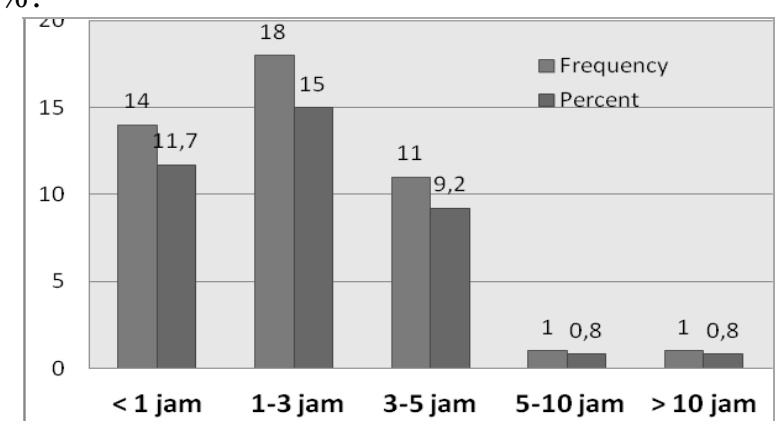

Grafik 26. Lama Penggunaan Smartphone oleh Individu (survei TIK BPSDMP Kominfo Surabaya 2017)

Melihat grafik 26 responden yang menyatakan menggunakan smartphone kurang dari 1 jam sebanyak 14 responden atau 11,7 \%, Lama menggunakan smartphone $1-3$ jam sebesar 18 responden atau 15,0 \%. Lama menggunakan smartphone 3-5 jam sebanyak 11 responden atau 9,2 \%. lama menggunakan smartphone 5- 10 sebanyak 1 responden atau 0,8 \% lebih lama menggunakan semartphon dari sepuluh jam hanya 1 responden atau $0,8 \%$.

Melihat grafik 27. Terkait lama penggunaan handphone $(2 \mathrm{G})$ yang menyatakan kurang dariu 1 jam sebanyak 51 responden atau 42,5\%. Lama penggunaan handphone 1-3 jam sebanyak 14 responden atau $11,7 \%$. Lama penggunaan handphone lebih dari sepuluh jam hanya 1 responden atau $0,8 \%$. 


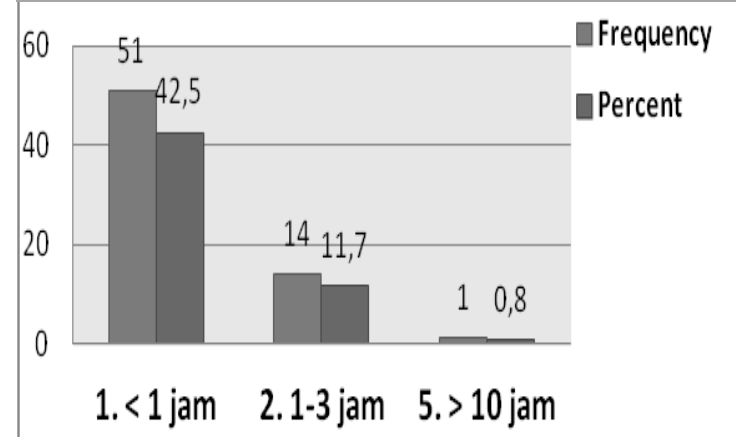

Grafik 27. Lama Penggunaan Handphone (survei TIK BPSDMP Kominfo Surabaya 2017)

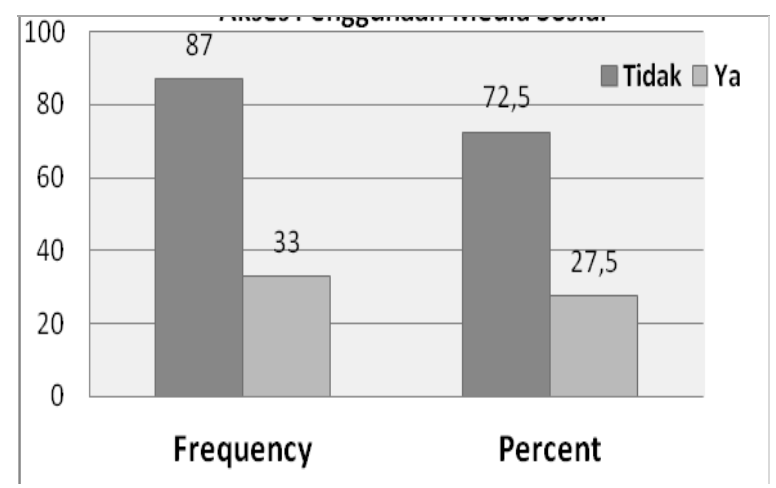

Grafik 28. Akses Pembangunan Media Sosial (survei TIK BPSDMP Kominfo Surabaya 2017)

Melihat grafik 28. Terkait Media sosial yang di akses responden, yang menyatakan ya mengakses media sosial sebanyak 33 responden atau $27,5 \%$. Tidak mengakses media sosial sebanyak 87 responden atau sebesar 72,5\%. Total sebesar 100,0 $\%$.

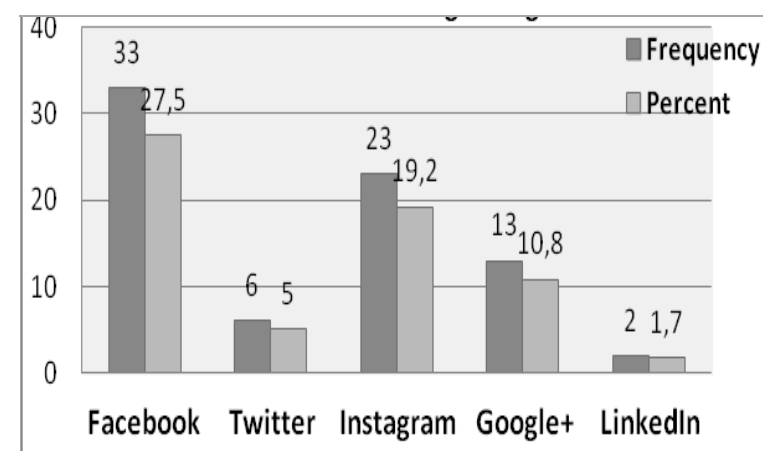

Grafik 29. Akses Pembangunan Media Sosial (survei TIK BPSDMP Kominfo Surabaya 2017)

Melihat grafik 29. Terkait akun media sosial yang sering di akses. Adalah facebook sebanyak 33 responden atau $27,5 \%$. Twitter sebanyak 6 responden atau 5,0 \%. Instagram sebanyak 23 responden atau 19,2\%. Google+ sebanyak 13 responden atau $10,8 \%$. Linkedin sebanyak 2 responden atau $1,7 \%$.

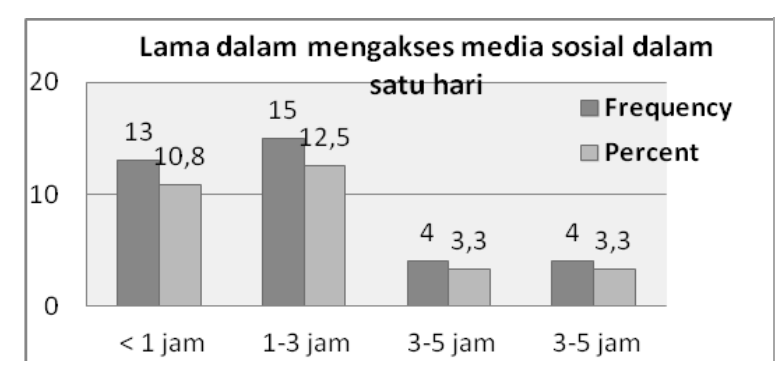

Grafik 30. Lama dalam Mengakses Media Sosial (survei TIK BPSDMP Kominfo Surabaya 2017)

Melihat grafik 30. Terkait Rata-rata dalam mengakses media sosial dalam satu hari. yang menyatakan < 1 jam mencapai sebanyak 13 responden atau 10,8 \%. 1-3 jam sebanyak 15 responden atau $12,5 \%$. 3-5 jam sebanyak 4 responden atau $3,3 \%$. sebanyak 23 responden atau $2,0 \%$. Tidak mengakses sebanyak 87 responden atau $72,5 \%$. Total sebesar $100,0 \%$

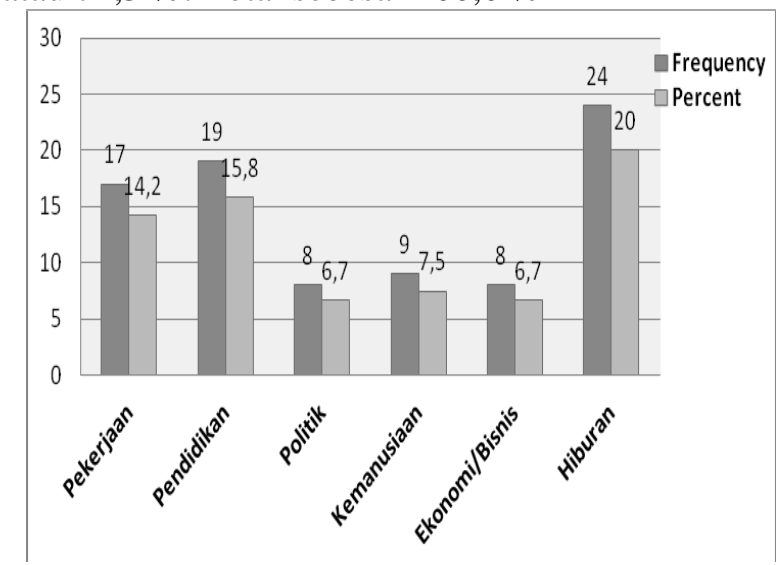

Grafik 31. Topik yg sering mjd perhatian responden di media sosial (survei TIK BPSDMP Kominfo Surabaya 2017)

Melihat grafik 31. Terkait Topik yang sering menjadi perhatian di media social. Pekerjaan sebanyak 17 responden atau $14,2 \%$. Pendidikan sebesar 19 responden atau $15,8 \%$. Politik sebesar 8 responden atau $6,7 \%$. Kemanusiaan sebanyak 9 responden atau 7,5\%. Ekonomi/bisnis/perdagangan sebanyak 8 responden atau $6,7 \%$. Hiburan sebanyak 24 responden atau $20,0 \%$.

Melihat grafik 32. Terkait Instant Messaging yang di akses Responden. Yang menyatakan ya sebanyak 39 responden atau 32,5\%. Yang menyatakan tidak mengakses Instant Messaging sebanyak 81 responden atau $67,5 \%$. Total sebesar $100,0 \%$. 


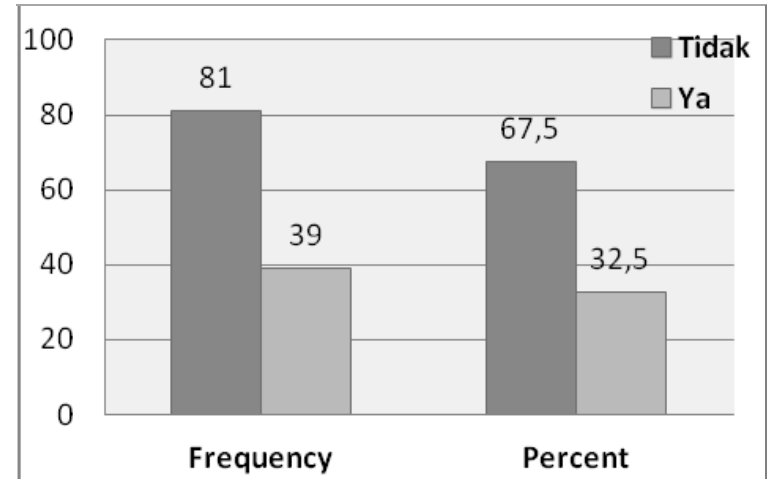

Grafik 32. Instant Messanging yg diakses individu (survei TIK BPSDMP Kominfo Surabaya 2017)

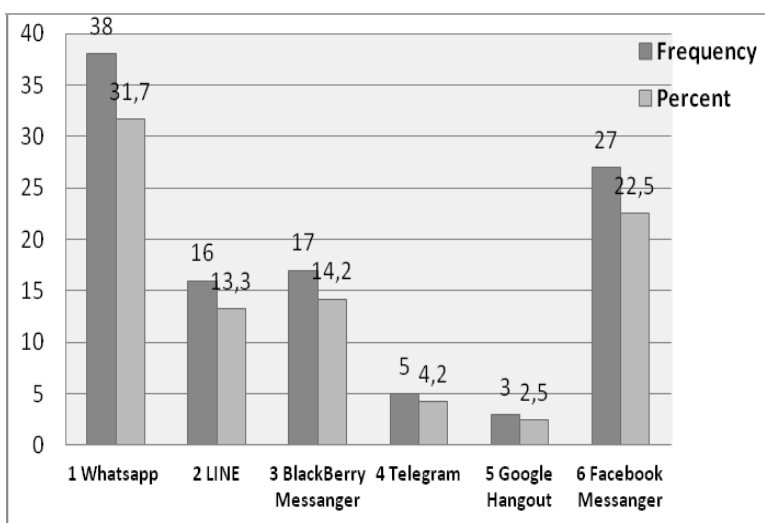

Grafik 33. Macam-macam aplikasi instant messanging yang sering digunakan (survei TIK BPSDMP Kominfo Surabaya 2017)

Melihat grafik 33 terkait macam-macam instant messaging yang sering digunakan. WhatsApp sebanyak 38 responden atau 31,7\%. line sebanyak 16 responden atau 13,3\%. Blackberry Messanger 17 responden atau $14,2 \%$. Telegram sebanyak 5 responden atau 4,2 \%. Google Hangout sebanyak 3 responden atau 2,5\%. Facebook Messanger sebanyak 27 responden atau 22,5\%.

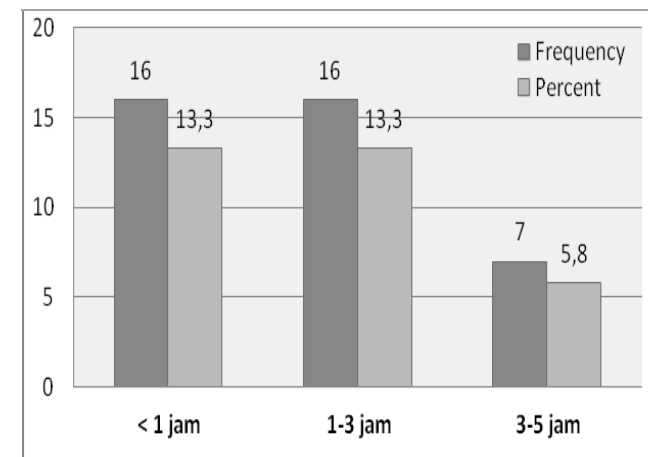

Grafik 34. Lama berkomunikasi melalui Instant Messaging oleh Individu (survei TIK BPSDMP Kominfo Surabaya 2017)

Melihat grafik 34. Terkait Lama Responden dalam Berkomunikasi melalui instant Massaging dalam satu hari, yang menyatakan $<1$ jam mencapai sebanyak 16 responden atau $13,3 \%$. yang menyatakan 1-3 jam sebanyak 16 responden atau $13,3 \%$. yang menyatakan 3-5 jam sebanyak 7 responden atau 5,8 \%. Tidak berkomunikasi melalui instant Massaging sebanyak 81 responden atau 67,5 $\%$. Total sebesar $100,0 \%$.

Melihat grafik 35. Terkait Instant Messaging yang diikuti responden. 1-5 grup mencapai 31 responden atau sebesar 25,8 \% . 6-10 grup mencapai sebanyak 4 responden atau $3,3 \%$. > 10 grup sebanyak 2 responden atau $1,7 \%$. Tidak tergabung dalam grup sebanyak 2 responden atau $1,7 \%$. Tidak menggunakan/tidak mengikuti sebanyak 81 responden atau $67,5 \%$. Total sebesar $100,0 \%$. Topik yang sering menjadi perhatian di grup instant messaging.

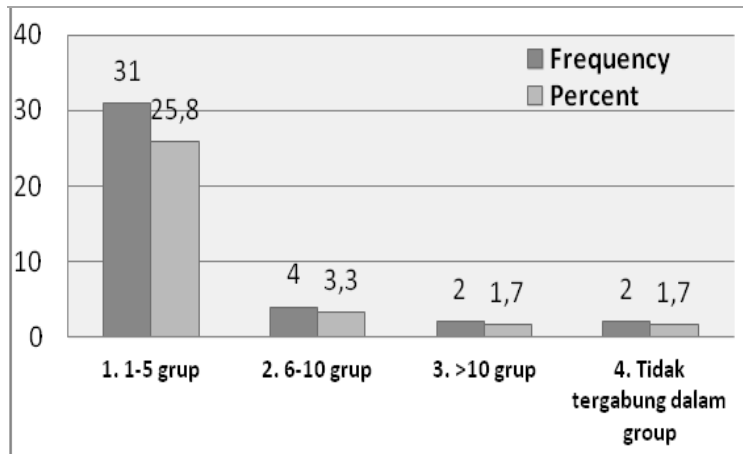

Grafik 35. Grup Instant Messaging yang diikuti Individu survei TIK BPSDMP Kominfo Surabaya 2017)

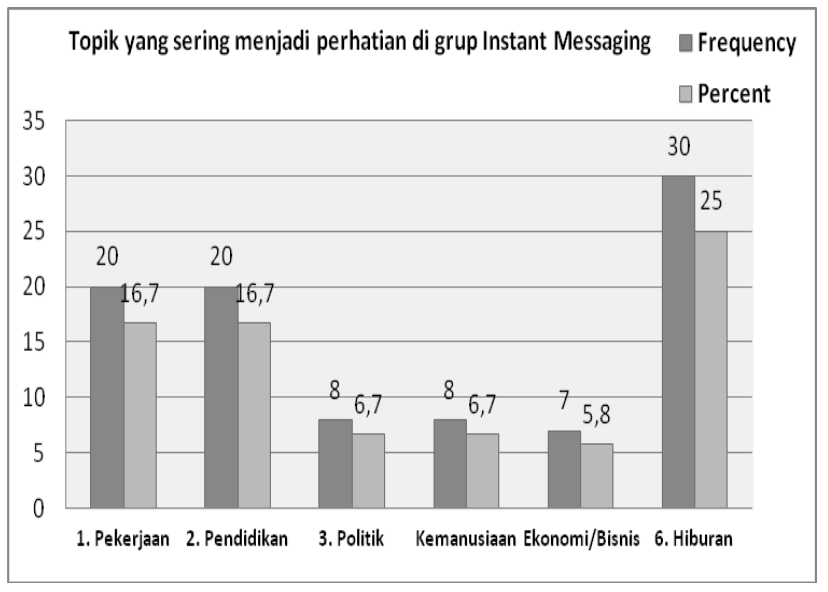

Grafik 36. Topik yang menjadi perhatian di grup Instant Messaging (survei TIK BPSDMP Kominfo Surabaya 2017)

Melihat grafik 36. Terkait topik yang sering menjadi perhatian di grup Instant Messaging topik pekerjaan sebanyak 20 responden atau $16,7 \%$. Topik pendidikan sebanyak 20 responden atau 16,7 $\%$. Topik politik sebanyak 8 responden atau $6,7 \%$. yang menyatakan topik kemanusiaan sebanyak 8 responden atau $6,7 \%$ yang menyatakan 
ekonomi/bisnis/perdagangan sebanyak 7 responden atau $5,8 \%$ yang menyatakan topik hiburan sebanyak 30 responden atau $25,0 \%$. Di grup instant messaging topik pekerjaan menjadi viral dibicarakan, karena saat ini ketepatan pelajar atau/mahasiswa lulus dari sekolah/universitas.

Melihat grafik 37 ternyata jenis kelamin lakilaki lebih sering menggunakan WhatsApp dari pada perempuan.

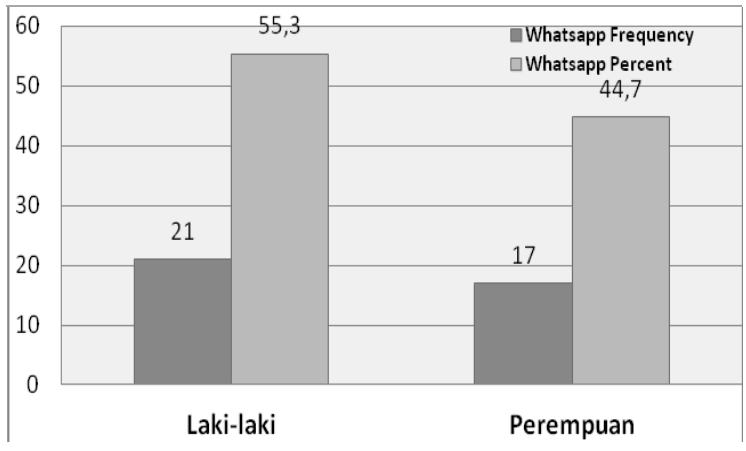

Grafik 37. Penggunaan Perangkat TIK Berdasarkan Crosstabulation (survei TIK BPSDMP Kominfo Surabaya 2017)

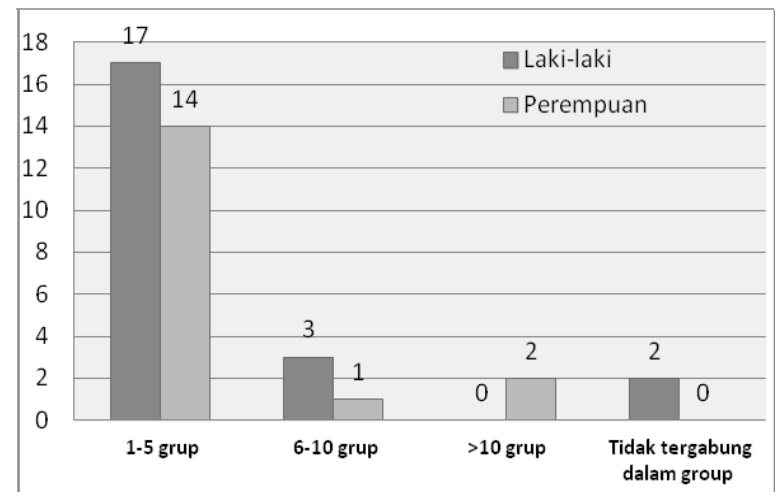

Grafik 38. Grup Instant Messaging yang di ikuti individu (survei TIK BPSDMP Kominfo Surabaya 2017)

Melihat grafik 38 laki-laki lebih banyak mengikuti grup Instant Messaging 1-5 grup sebanyak 17 responden, 6-10 grup sebanyak 3 responden, lebih dari 10 grup sebanyak 2 responden. Dan tidak ttergabung dalam grup 2 responden. Untuk Perempuan 1-5 grup sebanyak 14 responden, 6-10 grup 1responden, lebih dari 10 grup sebanyak 2 responden.

Melihat grafik 39 handphone (2G) digunakan untuk berkomunikasi rata-rata oleh SMP, untuk pengguna handphone (2G) ke 2 adalah berpendidikan terakhir $\mathrm{SD}$, sedangkan pendidikan SMA pengguna handphone $(2 \mathrm{G})$ ke tiga untuk berkomunikasi.

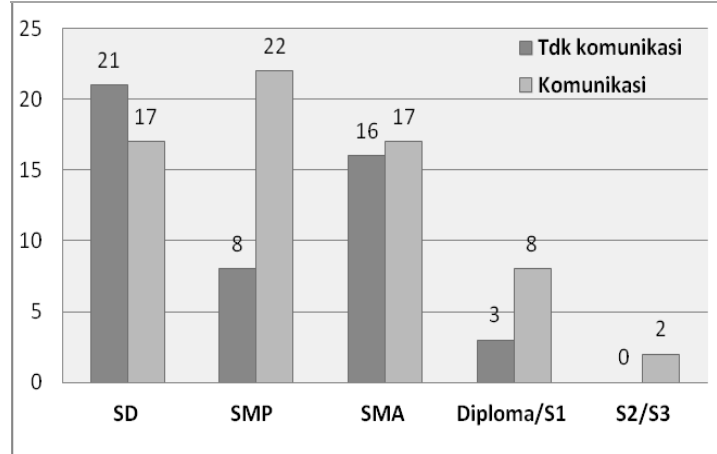

Grafik 39. Crosstabulation Penggunaan Handphone (2G) berdasarkan Pendidikan Terakhir (survei TIK BPSDMP Kominfo Surabaya 2017)

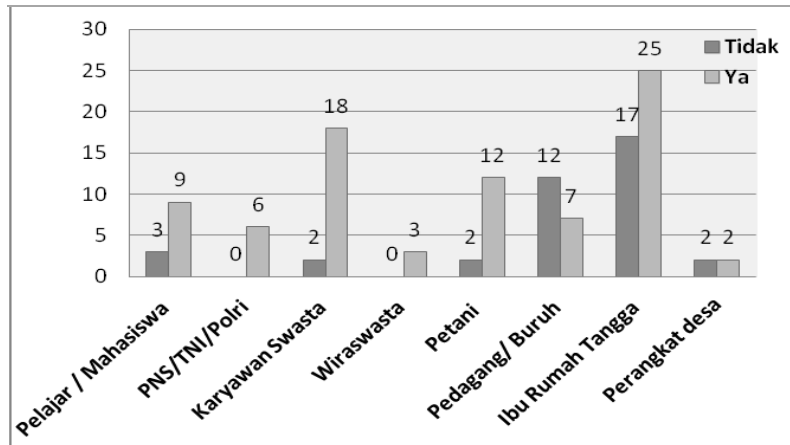

Grafik 40. Crosstabulation Penggunakan perangkat TIK, berdasarkan Pekerjaan (survei TIK BPSDMP Kominfo Surabaya 2017)

Melihat grafik 40 penggunaan perangkat TIK berdasarkan pekerjaan, ibu rumah tangga paling banyak menggunakan perangkat TIK yaitu 25 responden kedua karyawan swasta sebanyak 18 responden dan paling sedikit adalah perangkat desa.

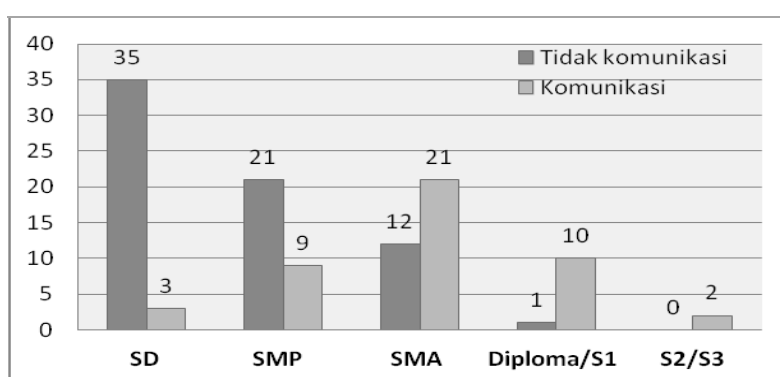

Grafik 41. Crosstabulation

Penggunaan Smartphone berdasarkan Pendidikan (survei TIK BPSDMP Kominfo Surabaya 2017)

Melihat grafik 41. Penggunaan Smartphone berdasarkan pendidikan adalah SMA paling dominan menggunakan Smartphone untuk berkomunikasi, urutan kedua SMP, urutan ketiga Diploma/S1. 




Grafik 42. Aplikasi Instant Messaging sering digunakan berdasarkan Pendidikan Terakhir (survei TIK BPSDMP Kominfo Surabaya 2017)

Melihat grafik 42 aplikasi Instant Messaging yang sering digunakan berdasarkan Pendidikan Terakhir adalah SMA paling sering menggunakan WhatsApp (WA). Yang kedua Diploma/S1 dan ketiga SMP.

\section{Pembahasan}

Profil responden jenis kelamin laki-laki lebih dominan dari pada perempuan tingkat pendidikan terakhir, yang dominan adalah SD. Pekerjaan responden yang paling banyak menduduki urutan pertama adalah ibu rumah tangga sebagian besar memiliki telepon rumah terkait pengeluaran perbulan, yang rata-rata kurang dari 1 juta.

Kepemilikan Perangkat TIK oleh individu sebagian besar rata-rata masyarakat sudah memiliki perangkat TIK. Sebagian kecil yang belum memiliki perangkat TIK, khususnya di masyarakat desa, karena penghasilannya masih rendah sehingga belum mampu membeli perangkat teknologi informasi dan komunikasi.

Macam-macam perangkat yang dimiliki masyarakat, paling banyak handphone (2G). Kedua smartphone ketiga laptop antara peringkat satu hingga ke tiga lagi dibutuhkan masyarakat. Misal seperti Handphone (2G) sebagian besar masih dimiliki dan digunakan oleh masyarakat desa, Smartphone saatnya sedang trend. Sedangkan laptop dibutuhkan dikalangan pelajar/mahasiswa.

Penggunaan perangkat TIK dalam 3 bulan terakhir. Sebagian besar Masyarakat menggunakan perangkat TIK. Sebagian kecil saja tidak menggunakan Perangkat TIK. Yang digunakan dalam 3 bulan terakhir. Sebagian besar rata-rata masih Handphone (2G). Smartphone menduduki urutan kedua. Laptop menduduki urutan ketiga.

Jenis akses internet yang digunakan secara bersama di rumah adalah Fixed Line dan Wireless Hotspot, namun tidak banyak masyarakat yang menggunakan jenis akses internet yang digunakan secara bersama di rumah. Karena saat ini masyarakat sudah tidak tergantung menggunakan internet dirumah cukup melalui HP dengan beli pulsa data internet secara paketan dimana saja sudah bisa menggunakannya akun media sosial yang sering di akses. Facebook, Instagram, google+, linkedIn, Twitter, Path, akun media sosial lainnya yang sering di akses WhatsApp, BBM, Youtube.

Lama Rata-rata dalam mengakses media sosial dalam satu hari, sebagian besar rata-rata 1-3 jam/hari. Topik yang sering menjadi perhatian di media social. Pertama hiburan. Kedua Pekerjaan. Ketiga ekonomi/bisnis/perdagangan grup instant messaging adalah topic pekerjaan menjadi ramai/viral dibicarakan, karena bertepatan dengan pendaftaran CPNS maka topik pekerjaan menjadi salah satu viral di instant messaging.

Akun Instant Messaging yang sering digunakan. Pertama WhatsApp. Kedua Blackberry Messanger. Ketiga Facebook Messanger. WA (WhatsApp). paling dominan digunakan. WA digunakan untuk bersilahturohim, sebagai sarana untuk penyampaian pesan sangat efektif baik kepada individu, kelompok maupun organisasi di tingkat pemerintah paling tinggi hingga sampai yang terendah seperti di tingkat RT, RW, dan pemerintahan kelurahan. WA sebagai alat komunikasi telah membentuk grup-grup, antara lain bisa dari teman sekolah, teman bekerja serta teman kuliah, hingga teman organisasi.

Lama rata-rata dalam berkomunikasi melalui instant Massaging dalam satu hari. kurang dari 1 jam mencapai mencapai 13,3\%. Sedangkan 1-3 jam mencapai $13,3 \%$. Sama-sama mencapai 13,3 $\%$. Pengguna perangkat TIK berdasarkan jenis kelamin crosstabulation ternyata jenis kelamin lakilaki lebih sering menggunakan WhatsApp daripada perempuan.

Laki - laki lebih banyak mengikuti grup Instant Messaging dari1-5 grup sebanyak 164 responden, 6-10 grup sebanyak 33 responden, lebih dari 10 grup sebanyak 21 responden. Tidak tergabung dalam grup 5 responden. Untuk perempuan yang mengikuti dari 1-5 grup sebanyak 130 responden, 6-10 grup 24 responden, lebih dari 10 grup sebanyak 12 responden.

Berdasarkan pendidikan penggunaan Handphone (2G) digunakan untuk berkomunikasi rata-rata oleh SMP, untuk pengguna handphone (2G) ke 2 adalah berpendidikan terakhir SD, sedangkan pendidikan SMA pengguna handphone (2G) ke tiga untuk berkomunikasi. 
Ibu Rumah Tangga paling banyak menggunakan perangkat TIK yaitu 25 responden, kedua karyawan swasta sebanyak 18 responden dan paling sedikit adalah perangkat desa.

Penggunaan smartphone berdasarkan Pendidikan adalah SMA paling dominan menggunakan Smartphone untuk berkomunikasi, sedangkan SMP urutan kedua dan Urutan ketiga Diploma/S1. Aplikasi Instant Messaging yang sering digunakan berdasarkan pendidikan terakhir adalah WhatsApp (WA) paling sering digunakan oleh SMA Yang kedua Diploma/S1 dan ketiga SMP.

\section{KESIMPULAN}

Secara individu profil responden Jenis kelamin laki-laki lebih dominan daripada perempuan Tingkat pendidikan terakhir, yang dominan adalah SD. Pekerjaan Responden yang paling banyak menduduki urutan pertama adalah Ibu Rumah Tangga. Sebagian besar memiliki telepon rumah. terkait pengeluaran perbulan, rata-rata kurang dari 1 juta.

Sebagian besar rata-rata secara individu sudah memiliki perangkat TIK. Sebagian kecil yang belum memiliki perangkat TIK, khususnya individu di rumah tangga yang tinggal di masyarakat desa, karena penghasilannya masih rendah sehingga belum mampu membeli perangkat teknologi informasi dan komunikasi. Alat komunikasi yang dimiliki responden, paling banyak handphone $(2 \mathrm{G})$, kedua smartphone, ketiga laptop.

Jenis akses internet yang digunakan secara bersama di rumah tangga, adalah Fixed Line dan Wireless Hotspot akun media sosial yang sering di akses oleh individu facebook dan WhatsApp, BBM, Youtube. Lama Rata-rata individu dalam mengakses media sosial dalam satu hari 1- 3 jam/hari.

Topik yang sering menjadi perhatian di media sosial hiburan. Di grup Instant Messaging adalah topik pekerjaan menjadi viral dibicarakan, karena bertepatan dengan pendaftaran CPNS akun Instant messaging yang sering digunakan adalah WhatsApp. Rata-rata lama berkomunikasi melalui Instant Massaging dalam satu hari kurang dari 1 jam dan kadang-kadang saja satu sampai tiga jam Pengguna Perangkat TIK Berdasarkan Crosstabulation

Ternyata jenis kelamin laki-laki lebih sering menggunakan WhatsApp daripada perempuan. Laki-laki lebih banyak mengikuti grup Instant
Messaging. Berdasarkan pendidikan, untuk pengguna HP (2G), SMP menduduki urutan pertama. Untuk pengguna ke 2 adalah SD untuk pengguna ke 3 adalah SMA dan HP (2G) digunakan hanya untuk komunikasi.

Ibu Rumah Tangga paling banyak menggunakan perangkat TIK. Kedua adalah karyawan swasta dan yang paling jarang menggunakan TIK adalah perangkat desa. Penggunaan Smartphone berdasarkan Pendidikan adalah SMA paling dominan menggunakan untuk berkomunikasi. Aplikasi Instant Messaging yang sering digunakan berdasarkan pendidikan terakhir (SMA) adalah WhatsApp (WA) yang kedua digunakan oleh Diploma/S1.

\section{REKOMENDASI}

Handphone $(2 \mathrm{G})$ secara individu masih banyak digunakan di masyarakat desa, karena belum mampu membeli perangkat teknologi yang lebih canggih dan banyak manfaatnya, seperti android tetapi juga sebagian besar belum mampu mengoperasialkan teknologi informasi dan komunikasi. Kesenjangan digital masih sangat kelihatan antara masyarakat desa dan kota.

Sebab itu saran dari tokoh masyarakat, pertama setiap titik kecamatan/desa diharapkan ada fasilitas akses yang bisa digunakan oleh masyarakat secara gratis, jadi masyarakat yang kurang mampu bisa akses di tempat yang sudah disiapkan oleh aparat desa. Kedua bagi yang belum mampu untuk menggunakan TIK, mengharapkan pihak terkait untuk memberikan pelatihan kepada mereka supaya bisa paham untuk mengetahui cara-cara dalam menggunakan Teknologi Informasi dan Komunikasi.

\section{DAFTAR PUSTAKA}

Arni, Muhammad (2005). Teori

Komunikasi. Jakarta: Bumi Aksara.

Effendy, Onong Uchjana. 1993. .Ilmu Komunikasi Teori dan Praktek. Bandung: PT Remaja Rosda Karya.

Hermawan, C.W. (2009). Cara Mudah Membuat Komunitas Online dengan PHPBB

Nurudin. (2012). Pengantar Komunikasi Massa. Jakarta: Rajawali Pers,

OECD. (2007). CSTD 2010-2011 inter-sessional panel 15-17 December 2010 Geneva, issues paper. 
Khoiri. Nur. (2011). Dampak Perkembangan Teknologi Komunikasi terhadap Kehidupan Sosial.

Liliweri Alo, (1991). Memahami peran Komunikasi Massa dalam Masyarakat. Bandung. P.T. Citra Aditya Bakti.

Severin Werner J Tankard James W. (2005). Teori Komunikasi, Prenada Jakarta.

Stephen W. Littlejonhn, Karen A. Foss, (2009). TEORI KOMUNIKASI Penerbit Salemba Humanika

Kominfo (2017). Proposal Survei Penggunaan TIK Serta Implikasinya Terhadap Aspek Sosial Budaya Masyarakat

Elysa Lubis (2014) Jurnal PARALLELA, Volume 1, Nomor 2, Desember 2014, hlm. 89-167

Trisnani. (2015). Jurnal Komunika Volume 4 Nomor3/November 2015. Halaman 139

Sejarah-ringkas-abad-21.html

http://scimla.blogspot.com/2016/06/global-villagemenurut-marshall-mcluhan.html

https://ebyvanhouten.wordpress.com/2014/10/17/tu gas-ilmu-sosial-dasar/ 